\title{
Acute Myocardial Infarction during Pregnancy
}

\author{
Jyotsna Maddury Indrani Garre \\ ${ }^{1}$ Department of Cardiology, NIMS, Punjagutta, Hyderabad, \\ Telangana, India
}

\begin{abstract}
Address for correspondence Jyotsna Maddury, MD, DM, FACC, FESC, FICC, Department of Cardiology, NIMS, Punjagutta, Hyderabad, TS 500082, India (e-mail: mail2jyotsna@rediffmail.com).
\end{abstract}

Indian J Cardiovasc Dis Women-WINCARS 2018;3:98-107

\begin{abstract}
Because of increase in the incidence of coronary artery disease (CAD) in younger population with increasing maternal age of pregnancy, the topic of acute myocardial infarction (AMI) during pregnancy has gained importance. Pathophysiologically AMI during pregnancy occurs more frequently due to coronary dissection, which is differ-

Keywords

- acute myocardial infarction

- coronary dissection

- dual antiplatelet drugs

- pregnancy ent in detection and management when compared with the atherosclerotic CAD. Dual antiplatelet drugs that are mandatory following AMI require modification before labor. In this review article, authors discuss in detail about the detection and management of $\mathrm{AMI}$ at different stages of pregnancy with the risk stratification and recommendations, including 2018 European Society of Cardiology (ESC) guidelines on "heart diseases during pregnancy."
\end{abstract}

\section{Introduction}

\section{Incidence and Prevalence}

The incidence of acute myocardial infarction (AMI) during pregnancy is rare, ${ }^{1}$ which is approximately 3 to 100 per 100,000 deliveries. ${ }^{2}$ However, pregnancy itself will increase the risk by threefold for the development of $\mathrm{AMI}^{3}{ }^{3}$ As this event to pregnant women increases the maternal mortality (11\%) in young age group along with fetal mortality (9\%), it requires special attention. ${ }^{4}$ Up to $4 \%$ of pregnancies may have cardiovascular complications despite no known prior disease. According to Smilowitz et al from National Inpatient Sample database, there was an increased incidence of AMI from 2014 when compared with 2002 (adjusted odds ratio [OR]: 1.25 [for 2014 vs. 2002]; 95\% confidence interval [CI]: $1.02-1.52$ ) with the occurrence rate of 1 for every 12,400 hospitalizations. ${ }^{4}$

\section{Period of Pregnancy}

Acute myocardial infarction occurrence risk is not confined only during the pregnancy period, but it extends 2 months beyond delivery also. According to Smilowitz et al, AMI most frequently occurred during the postpartum period accounting for $53.5 \%$, followed by during labor $(23.7 \%)$ and antepartum period (20.6\%). ${ }^{4}$ As per Elkayam's series also, AMI occurred most frequently in omit either in the third trimester or postpartum. AMI can occur in few cases during the first and second trimesters. Usually, AMI due to normal pregnancy predisposing factors causes myocardial infarction (MI) during the third trimester or peripartum, whereas other comorbidities either related to pregnancy or not contribute to AMI development during the first or third trimester.

\section{Type of Myocardial Infarction}

As per the series by Ladner et al, ST-elevation myocardial infarction (STEMI) occurred in $42.4 \%$ and rest were non-STelevation myocardial infarction (NSTEMI). ${ }^{1}$ A similar incidence was reported by Elkayam et al. ${ }^{5}$ Cardiogenic shock occurred in $6.5 \%$ of women. Takotsubo's cardiomyopathy was detected in $2.9 \%$ of patients. Anterior MI was the most common site (69\%) followed by inferior (27\%) and lateral MI (4\%). ${ }^{5}$

\section{Predisposing Factors for Acute Myocardial Infarction during Pregnancy \\ General Factors}

- Age: Women who had AMI were older (mean age 33.1 vs. 28.0 years; $p<0.001){ }^{4}$ Similarly in the series by Elkayam et al, $75 \%$ of AMI patients were in $>30$ years age group. ${ }^{5}$ With increase in maternal age every year, there is a $20 \%$ increase in MI risk.

- Associated cardiovascular comorbidities: AMI women had more cardiovascular comorbidities such as hypertension, diabetes, thrombophilia, tobacco use, dyslipidemia, 
known heart failure, anemia, renal insufficiency malignancy, strong family history of migraine headaches, and cocaine usage. ${ }^{6}$ With increasing maternal age and increasing coronary artery disease (CAD) in young patients, the number of preexisting CAD patients becoming pregnant is also increasing. Pregnancy may be considered in patients with known CAD in the absence of residual ischemia and clinical signs of left ventricular (LV) dysfunction.

\section{Specific to Pregnancy}

There are the factors contributing to the development of AMI during pregnancy-three to four times than nonpregnant age-matched women.

- Hypercoagulable state.

- Hormonal and hemodynamic changes in the cardiovascular system.

- Gestational diabetes and preeclampsia.

- Multiparty.

- Blood transfusion, postpartum infections, thrombophilia, postpartum hemorrhage. ${ }^{2}$

- Abnormal lipids-pregnancy itself causes dyslipidemia in the form of increased total cholesterol, low-density lipoprotein, and triglycerides, and decreases high-density lipoproteins. $^{\text {? }}$

\section{Pathophysiology of Acute Myocardial Infarction during Pregnancy}

\section{Sudden Coronary Artery Dissection}

Female sex is a risk factor for sudden coronary artery dissection (SCAD). ${ }^{8}$ Previous studies on AMI during pregnancy quoted SCAD in $43 \%,{ }^{5}$ but Smilowitz et al found it in $14.5 \%$ of cases. This pathology was more frequent in STEMI than NSTEMI (23.1\% vs. 8.2\%). ${ }^{4}$ SCAD may have single or multivessel involvement. The decreasing order of vessel involvement was the left anterior descending (LAD), left main coronary artery (LMCA), left circumflex artery (LCX), and right coronary artery (RCA). ${ }^{5}$ The probable mechanism for SCAD during pregnancy is mentioned in $\boldsymbol{- F i g} \mathbf{1}$.

Some of the pregnancy-related SCAD may have background connective tissue disorder or fibromuscular dysplasia. According to the series by Elkayam et $a l,{ }^{5}$ SCAD occurred in > $40 \%$ of patients. SCAD was found as a cause of AMI when AMI occurred during the peripartum period (which means late in pregnancy and early postpartum period). Another interesting finding in the series by Elkayam et al is preponderance of $L A D$ and left main (LM) involvement in CAD cases ( - Fig. 2).

\section{Atherosclerotic Disease: Seen in $\mathbf{2 7 \%}$ of Cases}

Thrombus: A clot without angiographic evidence for atherosclerotic disease was seen in $17 \%$ of cases. ${ }^{5}$ In addition, during

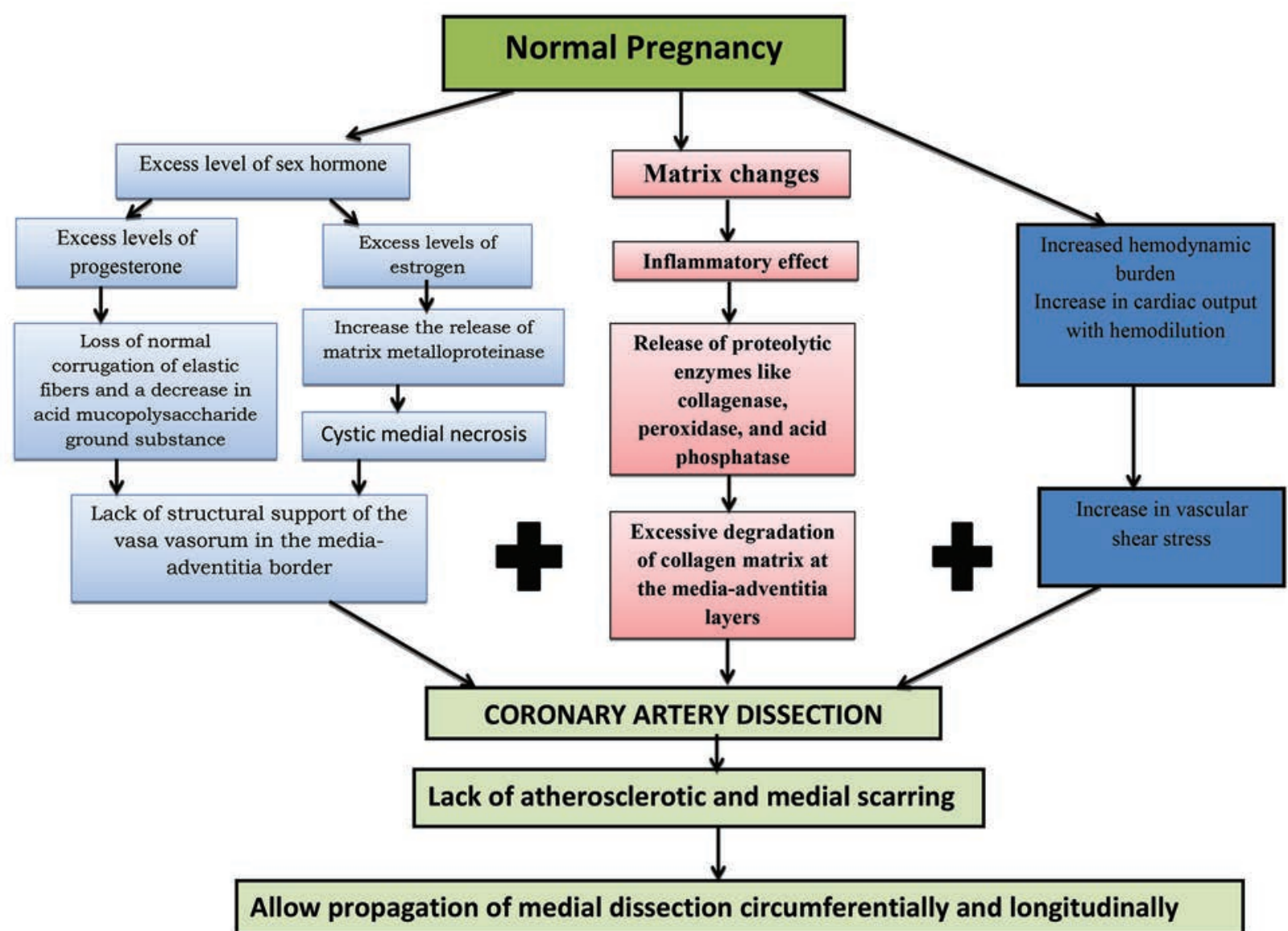

Fig. 1 Pregnancy predisposes to sudden coronary artery dissection-likely mechanism. ${ }^{24-26}$ 


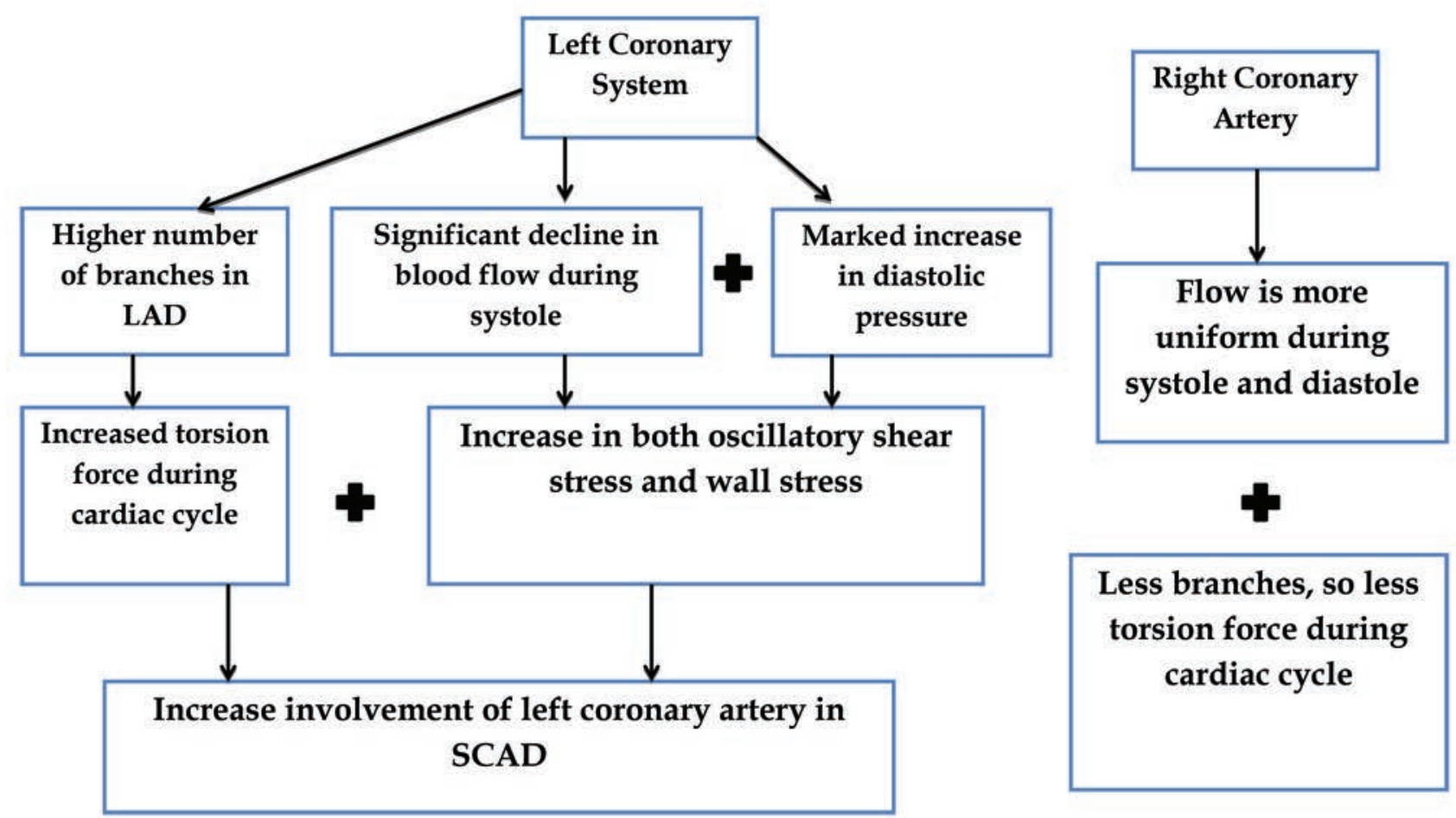

Fig. 2 Probable cause for frequent left coronary artery involvement in sudden coronary artery dissection (SCAD). ${ }^{5,27}$ LAD, Left anterior descending.

pregnancy deep vein thrombosis (DVT) with paradoxical embolization to coronaries should also be considered when thrombus is seen angiocardiographically.

\section{Normal Coronary Anatomy: Seen in 11\% of Patients}

Noniatrogenic coronary spasm was documented in two patients (-Fig. 3). ${ }^{5}$

Kawasaki disease in the past was an increasingly recognized cause for CAD in young population. It could be a cause in some pregnant women with AMI.

\section{Management of Acute Myocardial Infarction}

The European Society of Cardiology (ESC) has published guidelines on the management of cardiovascular disease during pregnancy. ${ }^{9}$

- Diagnosis: AMI during pregnancy is similar to that in nonpregnant women. Important differential diagnoses for AMI in pregnancy include pulmonary embolism, aortic dissection, and preeclampsia. These conditions are to be ruled out before going for specific management of ACS in pregnant women.

- Electrocardiogram: Even though new ST depressions, T-wave inversions (in inferior and lateral leads, small Q wave and inverted T wave in lead III, Q wave in lead aVF, inverted $\mathrm{T}$ waves in $\mathrm{V} 1, \mathrm{~V} 2$, and occasionally $\mathrm{V} 3$ ), and left-axis deviation (15-20 degrees) may be normally seen in pregnancy, ${ }^{6,10}$ ST elevations are never seen in normal pregnancy. Therefore, new ST elevation in two consecutive leads suggests AMI in the pregnant woman.

- Biomarkers: Increase in biomarkers during pregnancy should be interpreted based on of two parameters: timing of the blood sample and associated pregnancy-related complications. Normally creatine phosphokinase (CPK) is released from the uterus and placenta during labor. ${ }^{7}$ Rise in CPK starts immediately after delivery to 24 hours (sometimes up to four times the normal value) and then starts declining later. ${ }^{11}$ Therefore, during pregnancy depending only on CPK levels is not wise to diagnose AMI. Similarly, even troponin increase can occur in preeclampsia, gestational hypertension, and peripartum cardiomyopathy. ${ }^{11}$ In the absence of aforementioned conditions, an increase in troponin levels may be taken as substantial evidence for AMI diagnosis.

- Echocardiogram: New regional wall motion abnormalities (RWMAs) on echocardiogram during pregnancy suggest the coronary event. Increase or decrease in left ventricular mass is not specific for CAD; the increase is known to occur in preeclampsia and multiple gestations. ${ }^{12}$

- Treatment: Treatment is also generally the same in pregnancy with consideration of fetal effects.

\section{Medical Management}

- Thrombolytic management: Thrombolysis and thrombolytic drugs, according to 2004 ACC/AHA (American College of Cardiology/American Heart Association) guidelines, 


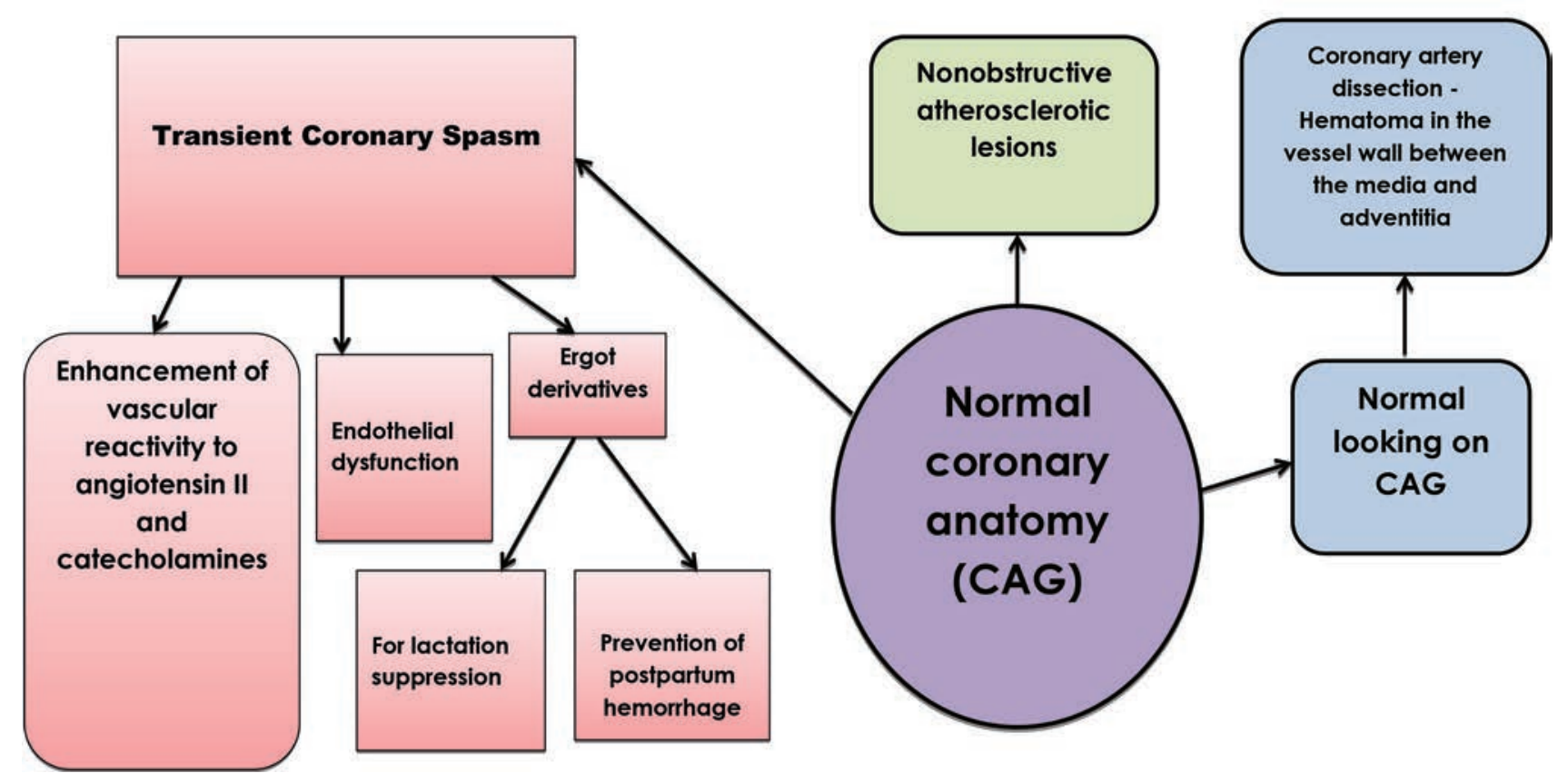

Fig. 3 Causes of normal coronary anatomy on coronary angiography (CAG) in acute myocardial infarction during pregnancy. ${ }^{3,5}$

are relatively contraindicated during pregnancy as these drugs can increase the risk of maternal hemorrhage. Subsequently changed as a relative contraindication. Pregnant women presenting with AMI may have coronary artery dissection causes and hence thrombolysis in these patients is contraindicated as dissection progression may occur. Details are given in - Table $\mathbf{1}$. Thrombolysis may be considered only in the centers that do not have percutaneous coronary intervention (PCI) access.

- Antiplatelet drugs: Low-dose aspirin (ASA) is safe in pregnancy during the second and third trimesters. ASA is secreted in breast milk in low concentrations without any adverse effect. The side effects of high-dose aspirin are mentioned in - Fig. 4 . There are no randomized studies for dual antiplatelet therapy (DAPT) regimen or for the safety of ticagrelor of prasugrel. Details are mentioned with antiplatelet regimen after PCI ( - Table $\mathbf{1}$ ).

\section{Invasive Management}

As per the series by Smilowitz et al, $25.1 \%$ of patients with AMI during pregnancy underwent coronary revascularization even though $53.1 \%$ underwent for invasive management. ${ }^{4}$

- Route of invasive procedure: Radial route is preferred as this decreases the radiation dose to the abdomen. During the learning stage, the radial route takes more time to do the procedure, but once that learning curve period is passed, radial route does not take longer time than a femoral route.

- Anticoagulation during PCI-unfractionated heparin (UFH): Conventional heparin is preferred for both the mother and fetus. If the patient has allergy to heparin, bivalirudin can be used. ${ }^{13}$ During pregnancy, there are increased levels of heparin-binding proteins, factor VIII, and fibrinogen, which can alter the pharmacokinetics of heparin. ${ }^{14}$ Therefore, monitoring with activated clotting time ${ }^{15}$ is useful for the therapeutic effect of heparin. Heparin does not cross the placenta, so it does not cause fetal complications but can produce uteroplacental junctional bleed. HIT (heparin-induced thrombocytopenia) can happen in $3 \%$ of patients. ${ }^{15}$

- Low-molecular-weight heparins: There are limited data on this molecule, even though case reports are available.

- Radiation precaution during PCI: Shielding the patient's back and abdomen with lead aprons and radial route of PCI minimize fetal radiation exposure. Even though there is much talk about the teratogenic effects of radiation for the fetus during pregnancy, the amount of fetal exposure during PCI (0.02 and $0.1 \mathrm{mSv})$ is well below the threshold for teratogenicity for any period of pregnancy. ${ }^{16} \mathrm{~A}$ disposable radiation protection sterile drape (Radpad; Worldwide Innovations \& Technologies, Inc.) is very lightweight when compared with conventionally used shields, which decreases radiation to an operator to be studied during pregnancy. Other methods such as using simple fluoroscopy, using lower magnification, using low fluoroscopy frame rates, and careful collimation decrease the radiation exposure.

- Primary percutaneous coronary angioplasty: - Fig. 5 shows the flowchart to follow during a case of AMI during pregnancy.

Even though iodinated contrast agent is known to produce fetal congenital hypothyroidism, its incidence is very less. The Contrast Media Safety Committee of the European 
Table 1 Following AMI the drugs and its effects during pregnancy and peripartum period

\begin{tabular}{|c|c|c|c|c|c|c|}
\hline Drug name & Indicated (I) & $\begin{array}{l}\text { Contraindicated } \\
\text { (CI) }\end{array}$ & $\begin{array}{l}\text { Secreted in } \\
\text { breast milk }\end{array}$ & Side effects & $\begin{array}{l}\mathrm{Cl} \text { period or } \\
\text { effect }\end{array}$ & Evidence (yes/no) \\
\hline $\begin{array}{l}\text { Low-dose } \\
\text { Aspirin }\end{array}$ & Yes & High dose & - & $\begin{array}{l}\text { Gastroschi- } \\
\text { sis, prema- } \\
\text { ture closure } \\
\text { of patent } \\
\text { ductus arte- } \\
\text { riosus }\end{array}$ & - & Yes \\
\hline Clopidogrel & - & - & - & - & $\begin{array}{l}\text { To be stopped } \\
\text { a week prior } \\
\text { to any region- } \\
\text { al anesthesia } \\
\text { procedures }\end{array}$ & $\begin{array}{l}\text { No-only cases; } \\
\text { clopidogrel remains } \\
\text { a widely used thieno- } \\
\text { pyridine in pregnancy } \\
\text { (pregnancy category B) }\end{array}$ \\
\hline Prasugrel & No & - & - & - & - & $\begin{array}{l}\text { Its use in STEMI during } \\
\text { pregnancy is not rec- } \\
\text { ommended in favor of } \\
\text { clopidogrel }\end{array}$ \\
\hline Ticagrelor & $\begin{array}{l}\text { Recommended } \\
\text { only for use dur- } \\
\text { ing pregnancy } \\
\text { when there are } \\
\text { no alternatives } \\
\text { and benefit } \\
\text { outweighs risk }\end{array}$ & - & - & - & - & Pregnancy category C \\
\hline Cangrelor & - & - & - & - & - & $\begin{array}{l}\text { No data on the safety } \\
\text { of cangrelor in human } \\
\text { pregnancy; there } \\
\text { have been reports of } \\
\text { increased incidence of } \\
\text { incomplete ossifica- } \\
\text { tion and unossified } \\
\text { hind limb metatarsals, } \\
\text { abortion, intrauter- } \\
\text { ine losses, and fetal } \\
\text { growth retardation in } \\
\text { animal studies. }\end{array}$ \\
\hline $\begin{array}{l}\text { Low molec- } \\
\text { ular heparin }\end{array}$ & $\begin{array}{l}\text { Significant } \\
\text { dose-response } \\
\text { variability }\end{array}$ & - & - & - & - & $\begin{array}{l}\text { Less well studied than } \\
\text { UFH }\end{array}$ \\
\hline $\begin{array}{l}\text { GP 2a/3b } \\
\text { inhibitors }\end{array}$ & $\begin{array}{l}\text { Reserving its } \\
\text { use during PCl } \\
\text { for patients at } \\
\text { high ischemic } \\
\text { risk, including } \\
\text { those with } \\
\text { prior myocar- } \\
\text { dial infarction, } \\
\text { high thrombus } \\
\text { burden, and } \\
\text { complex PCl. }\end{array}$ & - & - & - & - & $\begin{array}{l}\text { There are very limited } \\
\text { data regarding poten- } \\
\text { tial fetal effects (preg- } \\
\text { nancy category B) }\end{array}$ \\
\hline $\begin{array}{l}\text { Direct } \\
\text { thrombin } \\
\text { inhibitors }\end{array}$ & $\begin{array}{l}\text { DTI do not } \\
\text { bind plasma } \\
\text { proteins, and } \\
\text { therefore have a } \\
\text { more pre- } \\
\text { dictable dose } \\
\text { response than } \\
\text { UFH }\end{array}$ & - & - & - & $\begin{array}{l}\text { Using ar- } \\
\text { gatroban only } \\
\text { in those with } \\
\text { HIT (Heparin } \\
\text { induced throm- } \\
\text { bocytopenia) }\end{array}$ & $\begin{array}{l}\text { There are limited data } \\
\text { on its safety during } \\
\text { pregnancy (pregnancy } \\
\text { category B) }\end{array}$ \\
\hline
\end{tabular}


Table 1 (continued)

\begin{tabular}{|c|c|c|c|c|c|c|}
\hline Drug name & Indicated (I) & $\begin{array}{l}\text { Contraindicated } \\
(\mathrm{Cl})\end{array}$ & $\begin{array}{l}\text { Secreted in } \\
\text { breast milk }\end{array}$ & Side effects & $\begin{array}{l}\text { Cl period or } \\
\text { effect }\end{array}$ & Evidence (yes/no) \\
\hline $\begin{array}{l}\text { ACEls and } \\
\text { ARBs }\end{array}$ & - & Yes & $\begin{array}{l}\text { ACEI are } \\
\text { excreted in } \\
\text { breast milk } \\
\text { and thus } \\
\text { breastfeed- } \\
\text { ing should be } \\
\text { discontinued } \\
\text { during lacta- } \\
\text { tion period }\end{array}$ & - & $\begin{array}{l}\text { Teratogenic } \\
\text { effects-Cl in all } \\
\text { trimesters }\end{array}$ & Category C \\
\hline $\begin{array}{l}\text { Hydralazine } \\
\text { with/with- } \\
\text { out nitrates }\end{array}$ & $\begin{array}{l}\text { Yes-generally } \\
\text { the vasodilator } \\
\text { of choice during } \\
\text { pregnancy }\end{array}$ & - & - & - & - & - \\
\hline Statins & - & Yes & - & $\begin{array}{l}\text { Congenital } \\
\text { anomalies }\end{array}$ & - & - \\
\hline $\begin{array}{l}\text { Calcium } \\
\text { channel } \\
\text { blockers }\end{array}$ & $\begin{array}{l}\text { Relative indica- } \\
\text { tion }\end{array}$ & - & - & $\begin{array}{l}\text { Tocolytic; } \\
\text { applica- } \\
\text { tion and } \\
\text { potential } \\
\text { synergism } \\
\text { with magne- } \\
\text { sium sulfate } \\
\text { may induce } \\
\text { hypotension } \\
\text { (mother) } \\
\text { and fetal } \\
\text { hypoxia }\end{array}$ & - & $\begin{array}{l}\text { Recommended given } \\
\text { its benefits outweigh } \\
\text { the risks }\end{array}$ \\
\hline$\beta$-Blockers & $\begin{array}{l}\text { Relative indica- } \\
\text { tion }\end{array}$ & - & - & $\begin{array}{l}\text { Bradycardia } \\
\text { and hypo- } \\
\text { glycemia, } \\
\text { IUGR }\end{array}$ & - & $\begin{array}{l}\text { May be used with } \\
\text { caution if benefits } \\
\text { outweigh the risks }\end{array}$ \\
\hline Sorbitrates & Yes & - & - & Bradycardia & - & - \\
\hline
\end{tabular}

Abbreviations: ACEI, angiotensin-converting enzyme inhibitor; AMI, acute myocardial infarction; ARB, angiotensin receptor blockers; DTI, direct thrombin inhibitor; IUGR, intrauterine growth restriction; PCI, percutaneous coronary intervention; STEMI, ST-elevation myocardial infarction; UFH, unfractionated heparin.

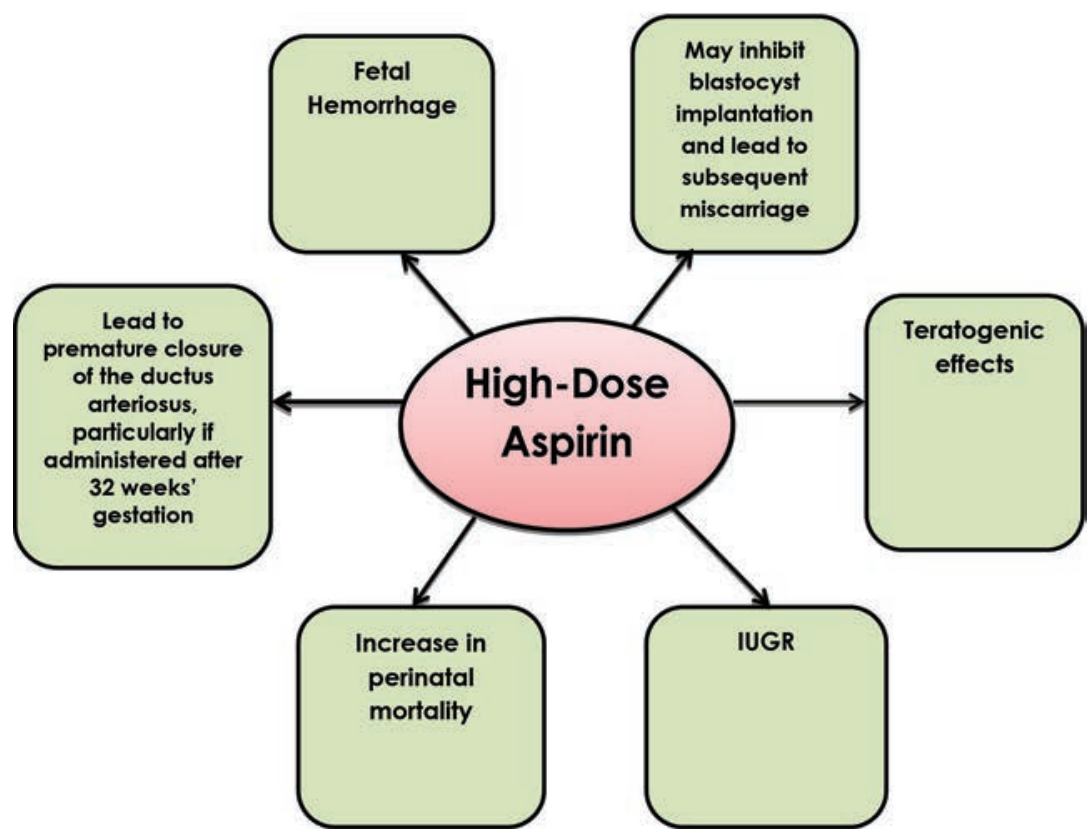

Fig. 4 Side effects of high-dose aspirin. IGUR, intrauterine growth retardation. 
Society of Urogenital Radiology and the American College of Radiology recommends only routine thyroid testing at the time of birth. ${ }^{17}$

Stent type: Bare-metal stent (BMS) is preferred over drug-eluting stent (DES) in patients undergoing primary $\mathrm{PCI}$ for AMI during pregnancy, especially if an event occurs in the third trimester. Four weeks of DAPT is safe with BMS PCI, to interrupt the DAPT before delivery. ${ }^{18}$

- Management drug regimen subsequently: - Table 1 gives the details of different drugs and its indications, which are essential for post-PCI.

- DAPT interruption during delivery: - Fig. 6 shows the algorithm for interruption of DAPT during pregnancy. ${ }^{19}$ Even in a case report, ${ }^{13}$ the antiplatelet regimen was not interrupted during labor and delivery.

\section{Surgical Management}

There are limited data on the surgical management of the AMI during pregnancy in the literature. ${ }^{20}$ In the series by Elkayam et al, coronary artery bypass grafting (CABG) was done in 30 patients, out of whom 23 had SCAD. CABG has done in 11 patients during pregnancy, rest of cases in the postpartum period. There was no maternal mortality, and only one fetal loss was reported. ${ }^{5}$

There is a suggestion that lower risk of fetal loss with contemporary surgery, which was substantiated by Immer et al. ${ }^{21}$

\section{Anesthesia Considerations}

Neuraxial (spinal, epidural, combined spinal-epidural) analgesia is the preferred modality for cesarean delivery for these patients with AMI complications. If required, epidural analgesia can be converted to epidural anesthesia. The major problem of neuroaxial anesthesia is hypotension, which can be minimized with low-dose local anesthetic technique and proper intravenous (IV) fluid management. Other important concern with this anesthesia is the epidural hematoma in patients who received DAPT. The algorithm for DAPT discontinuation is discussed subsequently.

\section{Management during Labor and Delivery}

In these patients with AMI complications, the treating physician should be individualized the patient who is to undergo vaginal or cesarean delivery ( $\mathbf{- F i g . ~ 7 ) . 1 3 , 2 2 , 2 3}$

\section{Complications}

\section{Maternal}

All mechanical, electrical, and myocardial loss complications occurring during AMI were known to occur in a pregnant patient with AMI with increasing incidence and mortality. As per the series by Elkayam et al, complications of heart failure or cardiogenic shock occurred in $38 \%$ of patients, ventricular arrhythmias in $12 \%$, recurrent angina or AMI in $20 \%$, and maternal mortality in $7 \% .{ }^{5}$ No complications were related to

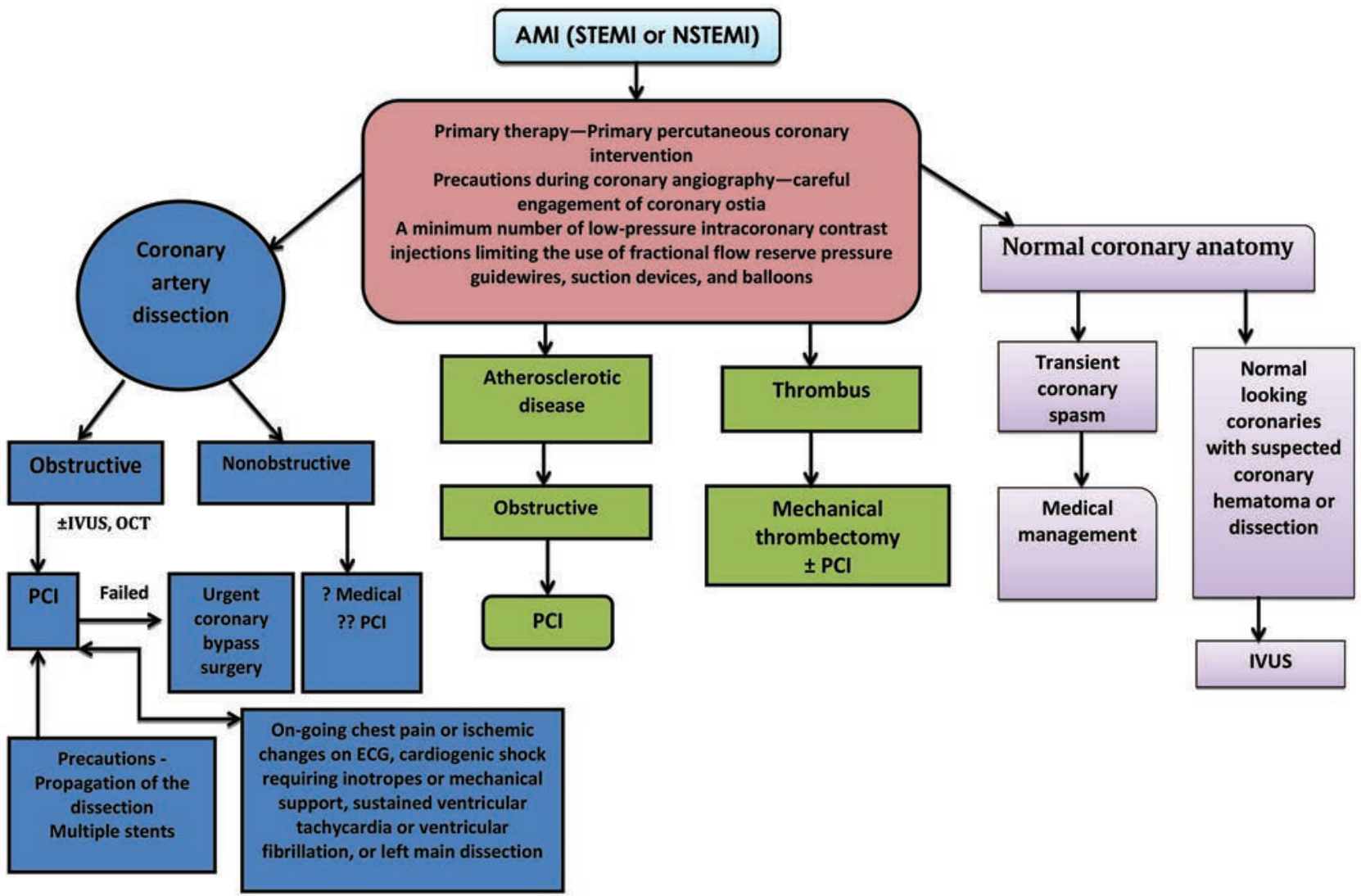

Fig. 5 Invasive management of acute myocardial infraction (AMI) during pregnancy and postpartum period. IVUS, intravascular ultrasound; NSTEMI, non-ST-elevation myocardial infarction; OCT, optical coherence tomography; PCI, percutaneous coronary intervention; STEMI, ST-elevation myocardial infarction. 


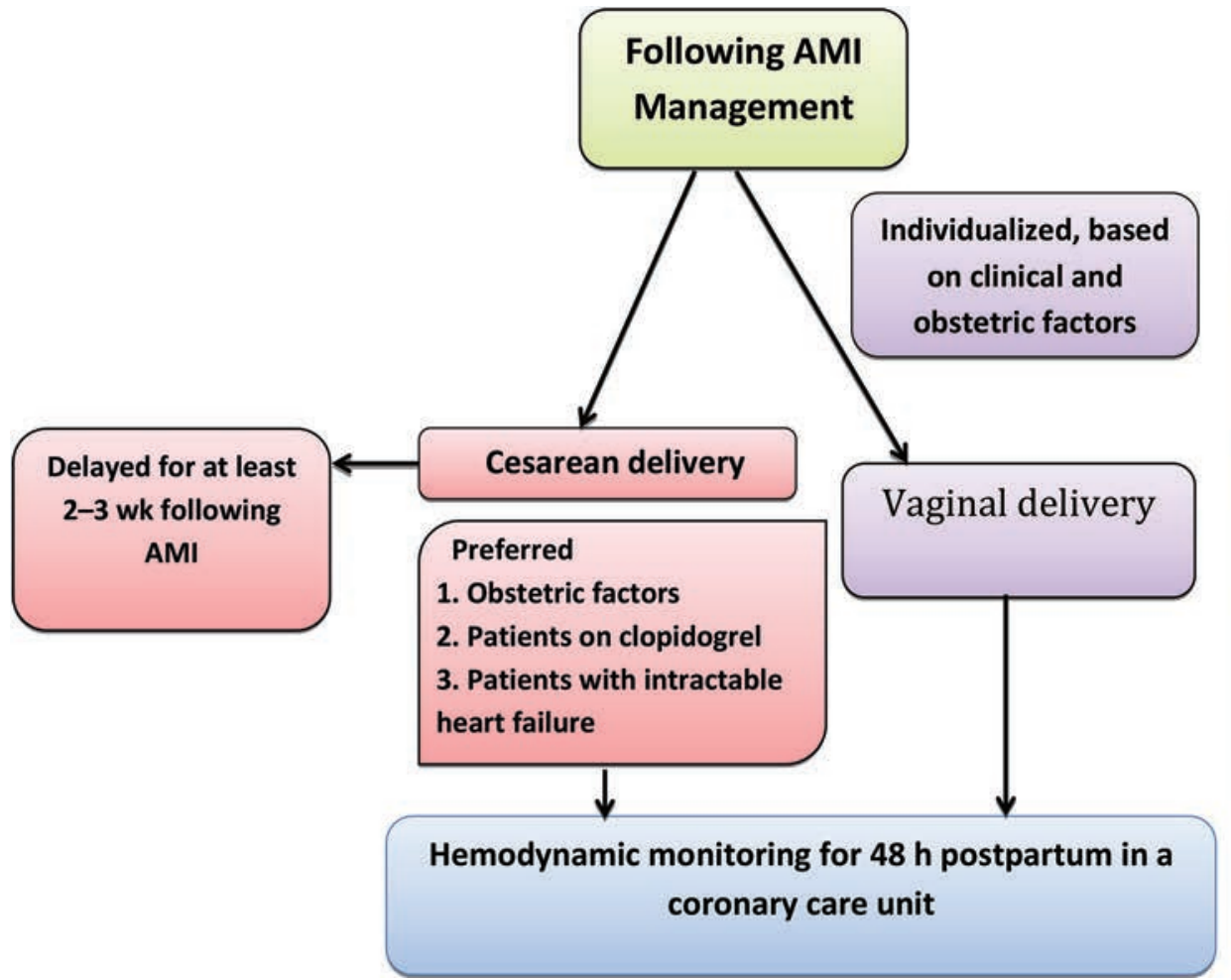

Precautions to be taken

1. Early continuous epidural anesthesia

2. Tachycardia and hypertension should be minimized

3. For hypotensionephedrine helps maintain placental perfusion

4. Avoid Ergot alkaloids immediately after delivery-risk of coronary artery spasm

Fig. 6 Management during labor and delivery of acute myocardial infarction (AMI) pregnant patient.

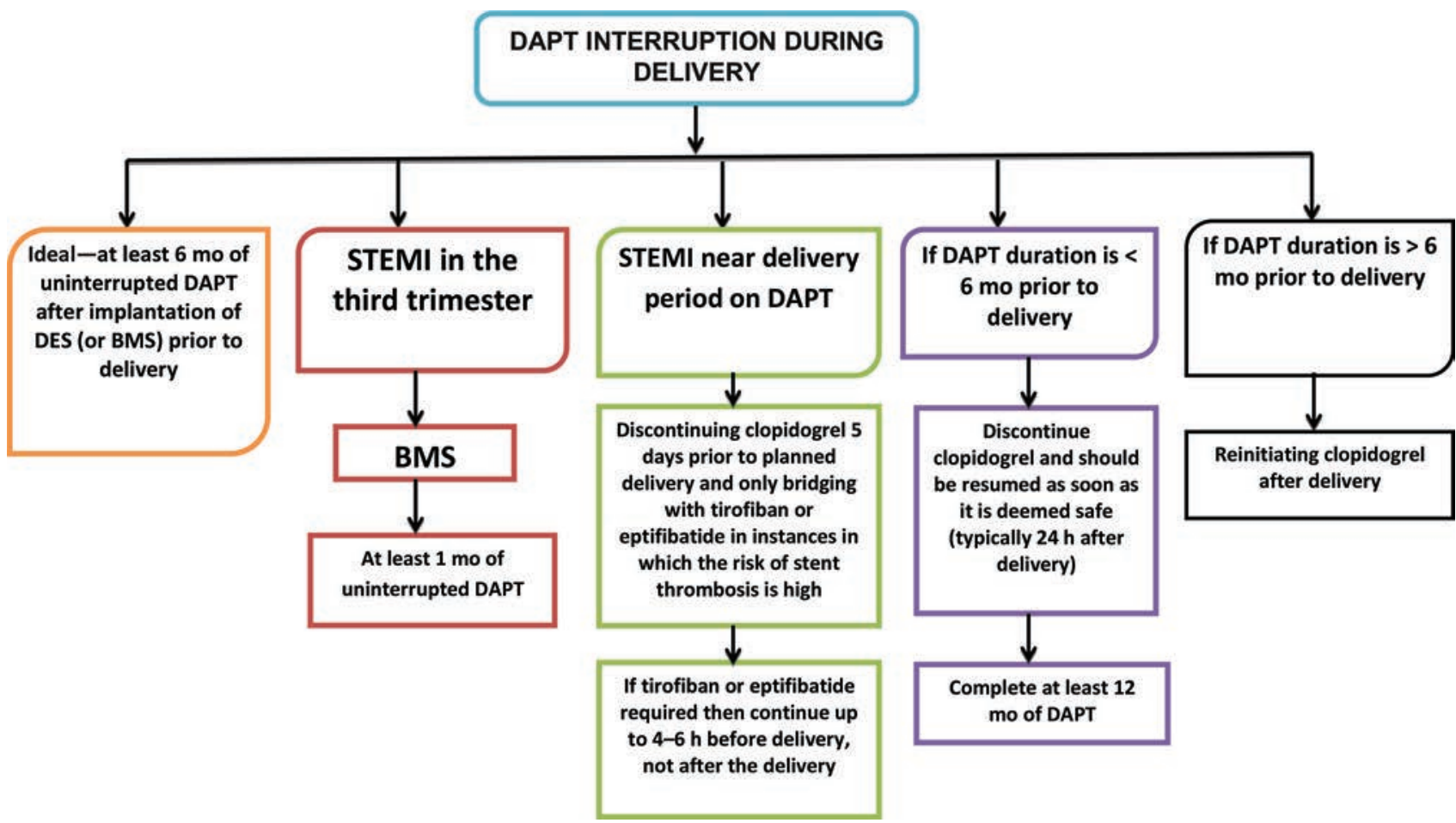

Fig. 7 Management during labor and delivery of acute myocardial infarction pregnant patient. ${ }^{19}$ BMS, bare-metal stent; DAPT, dual antiplatelet therapy; DES, drug-eluting stent; STEMI, ST-elevation myocardial infarction.

the drugs even with thrombolytic or GP2b/3a inhibitors in this series. ${ }^{5}$ The drugs that are safe and contraindicated from these conditions are mentioned in - Tables 1-3.
Intra-aortic balloon pump (IABP) can also be used safely during pregnancy if required for cardiogenic shock, but the patient should be in the left lateral position. ${ }^{18}$ 
Fetal

Most fetal deaths were associated with maternal mortality. There is decreasing trend from 1996 (20\%), 2008 (12\%) to 2011 (7\%).

\section{Follow-up and Prognosis}

As per the series by Smilowitz et al, the in-hospital mortality was 40-fold higher in patients with AMI than those without AMI during pregnancy (adjusted OR: 39.9; 95\% CI: 23.3-68.4; $p<0.001$ ), occurring at a rate of $4.5 \%$. Even though there is a substantial improvement in the management of AMI patients in general, it is not translated into the pregnant female population.

- Exercise test-for risk stratification of post-MI: At maximal maternal exercise, there may be fetal distress. Therefore, the submaximal protocol for fetal monitoring is advisable.

- Risk of subsequent pregnancies-SCAD: It recurred in $17 \%$ of patients in a median follow-up of 47 months. ${ }^{24}$ Therefore, subsequent pregnancy may not advisable.

\section{Changing Pattern of Acute Myocardial Infarction during Pregnancy over a Century}

Roth $^{3,5}$ compared the different studies from 1922 to 2011. which is divided into three periods: 1922 to 1995 (period 1),
1995 to 2005 (period 2), and 2006 to 2011 (period 3). The mean age was $>30$ years with multiparous status, hypertension, and diabetes as risk factors in all these periods except that family history of AMI is increased in periods 2 and 3. Comparing the coronary anatomy after AMI during pregnancy, stenosis was greater in period 1 (43\% vs. 27\%) than in period 3, and coronary dissection was reported to be higher in period 3 (16\% vs. $43 \%$ ) than in period 1 . Normal coronary anatomy was more frequent in period 1 (29\% vs. $11 \%$ ) than period 3.

There is decreasing tendency in maternal $(20,11$, and $7 \%)$ and fetal $(12,9$, and $5 \%)$ mortality in study periods 1,2 , and 3 , respectively.

Smilowitz et al reported similar changes in the 2002 to 2012 period of AMI complicated pregnancy in the U.S. population. ${ }^{4}$

\section{Conclusion}

Acute myocardial infarction during pregnancy is different from that in the age-matched nonpregnant woman, as both maternal and fetal mortalities are high. ESC 2018 guidelines on heart disease in pregnancy covered a few components of AMI during pregnancy; for example, testing tropin measurement in a pregnant patient with chest pain and primary PCI for STEMI during pregnancy are class 1 indications and invasive strategy for high-risk NSTEMI and conservative strategy for low-risk NSTEMI are class IIa indications.

Table 2 Acute myocardial infarction (AMI) complicated with heart failure-effect of drugs during pregnancy and peripartum period

\begin{tabular}{|l|l|l|l|l|l|}
\hline Drug name & Indicated (I) & Contraindicated (CI) & $\begin{array}{l}\text { Secreted in } \\
\text { breast milk }\end{array}$ & Cl period or effect & Evidence (yes/no) \\
\hline Furosemide & $\begin{array}{l}\text { Selective patients } \\
\text { only }\end{array}$ & Relative CI & & Category C \\
\hline Hydrochlorothiazide & Yes & $\begin{array}{l}\text { Yes-associated } \\
\text { with antiandrogenic } \\
\text { effects, oral clefts } \\
\text { (first trimester) }\end{array}$ & $\begin{array}{l}\text { Especially to avoid } \\
\text { during antepartum } \\
\text { period }\end{array}$ & Category C \\
\hline Spironolactone & Yes & $\begin{array}{l}\text { Risk of fetal respira- } \\
\text { tory compromise }\end{array}$ & Category C \\
\hline Morphine & & &
\end{tabular}

Table 3 Acute myocardial infarction (AMI) complicated with ventricular tachycardia-effect of drugs during pregnancy and peripartum period

\begin{tabular}{|c|c|c|c|c|c|}
\hline Drug name & Indicated (I) & $\begin{array}{l}\text { Contraindicated } \\
(\mathrm{CI})\end{array}$ & $\begin{array}{l}\text { Secreted in } \\
\text { breast milk }\end{array}$ & $\mathrm{Cl}$ period or effect & $\begin{array}{l}\text { Evidence } \\
\text { (yes/no) }\end{array}$ \\
\hline Lidocaine & Yes & & & & \\
\hline Amiodarone & $\begin{array}{l}\text { Is effective in virtually } \\
\text { all maternal and fetal } \\
\text { tachycardias; its use is } \\
\text { recommended only in } \\
\text { life-threatening cases } \\
\text { in which other thera- } \\
\text { pies have failed }\end{array}$ & Yes & $\begin{array}{l}\text { Yes-during } \\
\text { lactation is } \\
\text { discouraged }\end{array}$ & $\begin{array}{l}\text { Cl-thought the pregnan- } \\
\text { cy-fetal hypothyroidism } \\
\text { ( } 9 \% \text { of newborns of moth- } \\
\text { ers on chronic amiodarone } \\
\text { therapy), hyperthyroidism, } \\
\text { and goiter. }\end{array}$ & \\
\hline $\begin{array}{l}\text { Emergency } \\
\text { and elective } \\
\text { cardioversion }\end{array}$ & Yes & & & & \\
\hline
\end{tabular}


Newer guidelines for other components of management to these subgroups of patients with AMI during pregnancy are required. Coronary artery dissection is the frequent cause in AMI of pregnant women versus coronary stenosis in nonpregnant women. Treatment strategies also vary. For the selection of treatment strategy, we have to consider both maternal and fetal safety. DAPT regimen has to alter during delivery. At the same time, however, women should be informed about the paucity of information available on the safety of these drugs for their fetus. ${ }^{5}$ This topic requires special attention in gestational cardiology.

\section{Conflicts of Interest}

None.

\section{References}

1 Ladner HE, Danielsen B, Gilbert WM. Acute myocardial infarction in pregnancy and the puerperium: a population-based study. Obstet Gynecol 2005;105(3):480-484

2 James AH, Jamison MG, Biswas MS, Brancazio LR, Swamy GK, Myers ER. Acute myocardial infarction in pregnancy: a United States population-based study. Circulation 2006;113(12):1564-1571

3 Roth A, Elkayam U. Acute myocardial infarction associated with pregnancy. J Am Coll Cardiol 2008;52(3):171-180

4 Smilowitz NR, Gupta N, Guo Y, et al. Acute myocardial infarction during pregnancy and the puerperium in the United States. Mayo Clin Proc 2018;71(11 Suppl):S0025-6196(18)30356-2

5 Elkayam U, Jalnapurkar S, Barakkat MN, et al. Pregnancy-associated acute myocardial infarction: a review of contemporary experience in 150 cases between 2006 and 2011. Circulation 2014;129(16):1695-1702

6 Wuntakal R, Shetty N, Ioannou E, Sharma S, Kurian J. Myocardial infarction and pregnancy. Obstet Gynaecol 2013;15:247-255

7 Brizzi P, Tonolo G, Esposito F, et al. Lipoprotein metabolism during normal pregnancy. Am J Obstet Gynecol 1999;181(2):430-434

8 Hayes SN, Kim ESH, Saw J, et al; American Heart Association Council on Peripheral Vascular Disease; Council on Clinical Cardiology; Council on Cardiovascular and Stroke Nursing; Council on Genomic and Precision Medicine; and Stroke Council. Spontaneous coronary artery dissection: current state of the science: a scientific statement from the American Heart Association. Circulation 2018;137(19):e523-e557

9 Regitz-Zagrosek V, Blomstrom Lundqvist C, Borghi C, et al; European Society of Gynecology (ESG); Association for European Paediatric Cardiology (AEPC); German Society for Gender Medicine (DGesGM); ESC Committee for Practice Guidelines. ESC Guidelines on the management of cardiovascular diseases during pregnancy: the Task Force on the Management of Cardiovascular Diseases during Pregnancy of the European Society of Cardiology (ESC). Eur Heart J 2011;32(24):3147-3197

10 Mathew JP, Fleisher LA, Rinehouse JA, et al. ST segment depression during labor and delivery. Anesthesiology 1992;77(4):635-641
11 Shivvers SA, Wians FH Jr., Keffer JH, Ramin SM. Maternal cardiac troponin I levels during normal labor and delivery. Am J Obstet Gynecol 1999;180(1 Pt 1):122

12 Ghossein-Doha C, Peeters L, van Heijster S, et al. Hypertension after preeclampsia is preceded by changes in cardiac structure and function. Hypertension 2013;62(2):382-390

13 Jaiswal A, Rashid M, Balek M, Park C. Acute myocardial infarction during pregnancy: a clinical checkmate. Indian Heart 2013;65(4):464-468

14 Bates SM, Greer IA, Hirsh J, Ginsberg JS. Use of antithrombotic agents during pregnancy: the Seventh ACCP Conference on Antithrombotic and Thrombolytic Therapy. Chest 2004;126(3 Suppl):627S-644S

15 Amsterdam EA, Wenger NK, Brindis RG, et al; ACC/AHA Task Force Members. 2014 AHA/ACC guideline for the management of patients with non-ST-elevation acute coronary syndromes: a report of the American College of Cardiology/American Heart Association Task Force on Practice Guidelines. Circulation 2014;130(25):e344-e426

16 Conti CR. Cardiovascular studies and the radiation dose. Clin Cardiol 2009;32(2):56-57

17 Thomsen HS. European Society of Urogenital Radiology (ESUR) guidelines on the safe use of iodinated contrast media. Eur J Radiol 2006;60(3):307-313

18 Ismail S, Wong C, Rajan P, Vidovich MI. ST-elevation acute myocardial infarction in pregnancy: 2016 update. Clin Cardiol 2017;40(6):399-406

19 Horlocker TT, Wedel DJ, Rowlingson JC, et al. Regional anesthesia in the patient receiving antithrombotic or thrombolytic therapy: American Society of Regional Anesthesia and Pain Medicine Evidence-Based Guidelines (Third Edition). Reg Anesth Pain Med 2010;35:64-101

20 Arnoni RT, Arnoni AS, Bonini RCA, et al. Risk factors associated with cardiac surgery during pregnancy. Ann Thorac Surg 2003;76(5):1605-1608

21 Immer FF, Bansi AG, Immer-Bansi AS, et al. Aortic dissection in pregnancy: analysis of risk factors and outcome. Ann Thorac Surg 2003;76(1):309-314

22 Elkayam U, Gleicher N. Cardiac evaluation during pregnancy. In: Elkayam U, Gleicher N, eds. Cardiac Problems in Pregnancy. 3rd ed. New York, NY: Wiley-Liss; 1998:39-53

23 Kealey A. Coronary artery disease and myocardial infarction in pregnancy: a review of epidemiology, diagnosis, and medical and surgical management. Can J Cardiol 2010;26(6):185-189

24 Tweet MS, Hayes SN, Pitta SR, et al. Clinical features, management, and prognosis of spontaneous coronary artery dissection. Circulation 2012;126(5):579-588

25 Wingrove CS, Garr E, Godsland IF, Stevenson JC. 17beta-oestradiol enhances release of matrix metalloproteinase- 2 from human vascular smooth muscle cells. Biochim Biophys Acta 1998;1406(2):169-174

26 Alfonso F. Spontaneous coronary artery dissection: new insights from the tip of the iceberg? Circulation 2012;126(6):667-670

27 Chatzizisis YS, Giannoglou GD, Parcharidis GE, Louridas GE. Is left coronary system more susceptible to atherosclerosis than right? A pathophysiological insight. Int J Cardiol 2007;116(1):7-13 